\title{
Phytochemical Screening and Antimicrobial Activity of Vitex negundo Leaf and Stem Extracts against Bacterial and Fungal Pathogens
}

\author{
Alka Bameta $^{1 *}$, Shruti Sanwal ${ }^{1}$ and Sonu Ambwani \\ ${ }^{1}$ Department of Biotechnology and Allied Science, M. B. Govt. P. G. College, \\ Haldwani- 263139, India \\ ${ }^{2}$ Molecular Biology and Genetic Engineering College of Basic Sciences and Humanities, \\ G.B. Pant University of Agriculture and Technology, Pantnagar-263145, India \\ *Corresponding author
}

\section{A B S T R A C T}

\section{Keywords}

Antibacterial,

Antifungal, Extract,

Phytochemicals,

Vitex negundo

Article Info

Accepted:

1 November 2019

Available Online:

10 December 2019
Vitex negundo (family: Lamiaceae) is a medicinal shrub which is known to exhibit curative activity against several ailments like relieve catarrh, headache, reduce inflammatory swellings of joints in rheumatic attacks etc. In the present study, the bioactive compounds present in leaf and stem of Vitex negundo were investigated for antimicrobial activity against some pathogenic bacteria (Bacillus subtilis, Staphylococcus aureus, Pseudomonas aeruginosa, and Salmonella typhi) and fungus (Asparagus niger, Cryptococcus neoformans, Saccharomyces cerevisiae, Candida albicans). Dried leaf and stem samples were used to obtain various extracts viz. methanol, ethanol, petroleum ether, hexane and chloroform. The phytochemical analyses showed the presence of phenol, steroids, saponins, coumarin and reducing sugar in the various extracts used in this study. In antibacterial study, leaf hexane extract showed the highest inhibition zone against Pseudomonas aeruginosa while stem ethanolic extract was found to be most effective against Salmonella typhi. The methanol and ethanol leaf extracts were best recorded for the antifungal activity against Cryptococcus neoformans. The stem chloroform extract has also showed maximum inhibition in case of Cryptococcus neoformans growth.

\section{Introduction}

Medicinal plants are a precious natural resource, as they provide raw material for pharmaceutical industry, modern and traditional forms of medicine and generate employment and income in addition to conservation of bio-diversity and traditional knowledge (Balick and Mendelshon, 1992; Lambert et al., 1997). A perfect example of a medicinal plant credited with innumerable medicinal qualities validated by modern science and used since ancient times is $V$. negundo. $V$. negundo commonly known as Nirgundi is a woody, aromatic and medicinal shrub. Nirgundi is a Sanskrit word used for 
plant or any substance which protects the body from disease (Kamlesh and Vikrant, 1981). The genus Vitex belongs to the family Lamiaceae, which is mint family of flowering plants with 236 genera and more than 7000 species. It comprises of 250 known species (Boisser, 1888; Rechinger, 1987) distributed in Tropics and Sub Tropics It is commonly found in Eastern Africa, Madagascar to Iran, Burma, Pakistan, Srilanka, China, Taiwan, Afghanistan, India, Philippines, Thailand, throughout Malaysian region, Caroline Island and Moriana Islands. It is also widely cultivated in Europe, North America and West indies (Chauhan, 1999; Trease and Evans 2002). It is found in various places of India, like Andhra Pradesh, Assam, Bihar, Delhi, Gujrat, Haryana, Himachal Pradesh, Jammu \& Kashmir, Karnataka, Kerala, Madhya Pradesh, Uttar Pradesh, West Bengal and Uttarakhand (Germplasm Resources Information Network, 2011). Leaves are antiparisitic and used as alternative vermifuge and anodyne. They are also very effective to reduce inflammatory swellings of joints in rheumatic attacks, relieve catarrh and headache. The root is used as tonic, febrifuge, expectorant and diuretic. It regulates hormones, increases breast-milk production and possesses progesterogenic properties (Chevallier, 1996). Flowers are cool, astringent, carminative, hepatoprotective, digestive, febrifuge, vermifuge and are useful in haemorrhages and cardiac disorders. Fruit is nervine, cephalic, aphrodisiac, emmenagogue and vermifuge (Hussain et al., 1992).

Phytochemicals or secondary metabolites usually occur in complex mixtures that differ among plant organs and stages of development (Banerjee et al., 1969). Leaf extracts of Vitexnegundo possess anti-oxidant potential and antifungal activities (Tiwari and Tripathi, 2007), anthelminthic (Sharma, 2005), dysmenorrheal (Jadhav and Bhutani, 2005), medication and pain suppressing activity
(Dharmasiri et al., 2003), anti-hyperglycemic activity (Raj et al., 2008), Anti-filarial (Sathiamoorthy et al., 2007), Anti-bacterial (Samy et al., 1998) and opposed plant activity (Aswar et al., 2009). V. negundo contains number of phytochemicals or bioactive constituents which find ample use in the pharmaceutical industry.

Leaves contain an alkaloid nishindine, flavanoids like flavones, luetolin 7 glucoside, casticin, iridoidglucosides, an essential oil and other constituents like vitamin $\mathrm{C}$, carotene, gluconanitol, benzoic acid and $\mathrm{C}$ - glucoside. Bark contains fatty acids, beta sitosterol, phydroxy benzoic acid and luteolin. Stem bark contains leucoanthocyanidins. The present study was undertaken to investigate the phytochemical analysis and antimicrobial activity of different extracts.

\section{Materials and Methods}

\section{Collection of sample}

The samples including leaves and stems of $V$. negundo were collected from Kaladhungi (Uttarakhand State) during March 2013, situated in the Nainital District of Kumaun region of Uttarakhand state $\left(29.13^{\circ} \mathrm{N} 79.31^{\circ} \mathrm{E}\right)$ at an average elevation of $425 \mathrm{Mts}$ above sea level (Figure 1).

\section{Preparation of the extract}

The plant materials (leaf and stem) were surface sterilized and shade-dried at ambient temperature $\left(31^{\circ} \mathrm{C}\right)$ and were powdered using an electronic blender. The $10 \mathrm{gm}$ powdered mixture was then soaked in $20 \mathrm{~mL}$ of different solvents (ethanol, methanol, petroleum ether and chloroform) for $72 \mathrm{hrs}$. After that all filtered extracts were kept at room temperature for evaporation of solvents. The $20 \mathrm{mg} / \mathrm{mL}$ concentration of extracts was then used for phytochemical analysis. 


\section{Phytochemical screening (Brinda and Test for coumarins}

\section{Sarswatih, 1981)}

The plant extracts methanol, ethanol, petroleum ether and chloroform were subjected to phytochemical analysis of the active compounds present in them.

The compounds screened through qualitative biochemical assays to ascertain presence of reducing sugar, phenol, saponin, steroid and coumarin.

\section{Reducing sugars}

First, the extract $(1 \mathrm{ml})$ was added to $1 \mathrm{ml}$ of water and 20 drops of boiling Fehling's reagent in a test tube was added too.

The formation of a precipitate red-brick in the bottom of the tube indicates the presence of reducing sugars.

\section{Test for phenols}

To $1 \mathrm{ml}$ of extract of sample, $2 \mathrm{ml}$ of distilled water followed by few drops of $10 \%$ aqueous ferric chloride solution were added. Formation of blue or green color indicated the presence of phenols.

\section{Test for saponins}

To $1 \mathrm{ml}$ of extract was added few volume of distilled water in a test tube. The solution was shaken vigorously and observed for a stable persistent froth for $20 \mathrm{~min}$.

\section{Test for steroids}

$1 \mathrm{ml}$ of extract was taken in test tube with minimum quantity of chloroform and added 34 drops of acetic anhydride followed by one drop of conc. Sulfuric acid. The color changed from violet to blue green which indicated the presence of seroids.
Take extract $(5 \mathrm{ml})$ in test tube and add $2 \mathrm{ml}$ of $10 \% \mathrm{NaOH}$ into it. Boiled for 5 minutes, yellow color indicates the presence of coumarin.

Selection of microbial culture for antimicrobial activity

Bacillus subtilis (gram +ve), Staphylococcus aureus (gram +ve), Pseudomonas aeruginosa (gram-ve), Salmonella typhi (gram-ve), Aspergillus niger, Cryptococcus neoformans, Saccharomyces cerevisiae and Candida albicans were selected for the study of antibacterial and antimicrobial activity. The cultures were maintained on nutrient agar. The 24 hours grown broth cultures of the selected species were used for the antimicrobial screening.

Determination of antimicrobial activitydisc diffusion method (Maruzzella and Henry, 1958)

Nutrient Agar (NA) plates were seeded with 8 $\mathrm{h}$ brothculture of different bacteria while potato Dextrose Agar (PDA) plates were seeded with spore suspension of fungi. The disc $(5 \mathrm{~mm})$ of Whatman no 1 filter paper was soaked in crude extracts $(20 \mathrm{mg} / \mathrm{mL})$ in different solvents (methanol, ethanol, chloroform and petroleum ether) was placed carefully in the center of Petri-plates containing the solidified media.

To compare the antimicrobial activity, same concentration of the solvent using disc is placed in the plate which acts as a control to tested crude solvents. The plates were then incubated at $37^{\circ} \mathrm{C}$ for $18-24 \mathrm{~h}$ for bacterial pathogens and 3 days for fungal pathogens. The antimicrobial activity was evaluated by measuring the diameter of inhibition zone with the help of the ruler. The experiment was 
carried out in triplicate and the mean of the diameter of the inhibition zones was calculated.

\section{Statistical analysis}

Three replicates of each sample were taken and experiments were repeated thrice. The statistical analysis was done by two-way ANOVA and significance of differences between replicates were measured at $5 \%$ $(\mathrm{P}<0.05)$.

\section{Results and Discussion}

\section{Phytochemical analysis}

The present study carried out on the plant revealed the presence of various active phytochemicals. The Phytochemical test from five different leaf and stem crude extracts showed that V.negundocontains various phytochemical constituents like reducing sugar, phenol, saponins, steroid and coumarin (Figure 2). It was found that leaf chloroform crude extract contain maximum number of phytochemical constituents (reducing sugar, saponins, steroid and coumarin) followed by hexane (i.e. reducing sugar, phenol and coumarin). While ethanol, methanol and petroleum ether shows the presence of phenol, saponin, coumarin respectively. Paria et al., (2012) also investigated the presence of various phytochemicals and found that leaf extracts contain different chemical constituents i.e. reducing sugar, tannins, phenols, sterols, saponins and flavonoids. The results of stem extracts revealed that among various crude extracts, petroleum ether, ethanol and chloroform contain equal number of phytochemical constituents followed by hexane, while methanolic crude extract showed minimum number of phytochemical constituents (coumarin). Petroleum ether and ethanolic extracts showed the presence of phenol, saponin and steroid while in case of chloroform crude extract reducing sugar coumarin and phenol were present. In case of hexane, phenol and reducing sugar were present. The similar findings were obtained by Merlin and Cathrine (2011) while studying the Preliminary Phytochemical Screening and Antibacterial activity of Vitex negundo. They found that V.negundo contain various Phytochemical constituents like phenol, steroid, carbohydrates, quinines and flavonoids. Chitra et al., (2009), reported the preliminary phytochemical analysis on the crude ethanol extract which indicated the presence of alkaloids, glycosides, lignin, flavonoids and saponins. The various chemical constituents like flavonoids, flavone glycosides, volatile oil, triterpenes, tannins and lignin many others were identified and reported from Vitex negundo by Gautam et al., (2008) (Table 1).

\section{Antibacterial activity}

In the present study leaf extract showed activity against all bacterial cultures i.e. $S$. aureus, B. subtilis, Pseudomonas aeruginosa and $S$. typhii. Maximum zone of inhibition (i.e. $18.5 \pm 1.36 \mathrm{~mm}$ ) recorded in case of hexane crude extract, was against Pseudomonas. Methanolic crude extract showed activity against all bacterial strains except Pseudomonas. Maximum activity was shown by B. subtilis $(7.33 \pm .35 \mathrm{~mm})$ followed by $S$. aureus $(5.63 \pm 0.77 \mathrm{~mm})$ and $S$. typhi $(2.7 \pm 0.3 \mathrm{~mm})$. In case of ethanolic extract maximum zone of inhibition was displayed by $S$. aureus and $B$. subtilis $(7.96 \pm 0.55 \mathrm{~mm})$ followed by Pseudomonas (5.73 \pm 0.64$)$. Negative result was observed against $S$. typhi. Petroleum ether extract showed highest activity against $B$. subtilis and Pseudomonas $(13.0 \pm 0.3 \mathrm{~mm})$ as compared to $S$. typhi $(5.56 \pm 1.4 \mathrm{~mm})$, no activity was recorded against $S$. aureus. Chloroform extract was active against only Pseudomonas and S. typhi with $12.33 \pm 1.5$ and $8.16 \pm 1.2 \mathrm{~mm}$ diameter of inhibition zone (Table 2 and Figure 3). Panda et al., (2009) studied antibacterial activity of 
leaves \& bark of Vitex negundo against some gram +ve bacteria (S. epidermidis, B. subtilis and $S$. aureus) and Gram-ve bacteria (E. coli, $S$. typhimurium, $P$. aeruginosa, V. cholera and $V$. alginolyteus. All the extracts showed activity against $E$. coli and $S$. aureus. Ethanol and methanol extracts of leaf showed activity against gram +ve and gram -ve bacteria whereas petroleum ether and chloroform extracts of bark had better activity against gram +ve bacteria. Valsraj et al., (1997) reported antibacterial activity of leaves against four bacteria i.e. B. subtilis, $P$. aeruginosa, $E$. coli and $S$. epidermidis. Antimicrobial potential of $V$. negundo Linn. Leaf ethanol extract were investigated against different bacterial cultures (E. coli, S. aureus and $K$. pneumoniae) by Deogade et al., (2016). 20 $\mathrm{mg} / \mathrm{ml}, 40 \mathrm{mg} / \mathrm{ml}, 60 \mathrm{mg} / \mathrm{ml}, 80 \mathrm{mg} / \mathrm{ml}, 100$ $\mathrm{mg} / \mathrm{ml}$ of leaf extract was used to detect activity and found that the maximum zone of inhibition observed for $S$. aureus $15 \mathrm{~mm}$ at the concentration of $80 \mathrm{mg} / \mathrm{ml}$ and $100 \mathrm{mg} / \mathrm{ml}$ and for $E$. coli and $K$. pneumoniae maximum ZOI noted was $12 \mathrm{~mm}$ and $11 \mathrm{~mm}$ at $100 \mathrm{mg} / \mathrm{ml}$ concentration respectively. Stem extracts were active against $S$. aureus, Pseudomonas and $S$. typhi. Maximum activity was observed in case of ethanolic crude extract against $S$. typhi (i.e. $13.06 \pm 0.90 \mathrm{~mm}$ ) followed by petroleum ether against Pseudomonas with $10.33 \pm 0.65 \mathrm{~mm}$ inhibitory zone. Methanolic extract was recorded active against all bacterial strains except Pseudomonas. Maximum inhibition in case of methanolic extract was observed against $B$. subtilis followed $S$. aureus and $S$. typhi with $7.33 \pm 0.35,5.63 \pm 0.77$ and $2.7 \pm 0.3$ respectively. Zone of inhibition against $S$. aureus in petroleum ether crude extract was recorded around $8.73 \pm 0.64 \mathrm{~mm}$. No activity was observed in chloroform and hexane crude extracts (Table 2 and Figure 4). Similar results were reported by Jeyachandran et al., (2010) in which the ethanolic extract of Nerium oleander showed maximum zone of inhibition against Salmonella typhi. Aboud (2015) also reported that ethanol extracts of Nerium oleander showed highest activity other than aqueous extract. The highest activity was demonstrated by the ethanol extract against Staphylococcus aureus and Klebsiella spp.

\section{Antifungal activity}

Antifungal activity of Vitex negundo fruits against C. albicans, C. glabrata, A. flavus, $M$. canis and $F$. solani reported by Mahmud et al., (2009). Ethanol extract of fruit seeds showed significant activity against $F$. solani and moderate response against $M$. canis with no effect on $C$. albicans. In present study antifungal activities of Vitex negundo leaf and stem extract were determined against fungal isolates namely $A$. niger, $C$. neoformans, $S$. cerevisiae and $C$. albicans (Table 3). Leaf methanolic extract showed antifungal activity against all fungal strains. Maximum zone of inhibition was reported against $C$. neoformans $(14.76 \pm 1.42 \mathrm{~mm})$ followed by $A$. niger (8.33 \pm 1.33$), C$. albicans $(8.33 \pm 0.57)$ and $S$. cerevisiae $(6.26 \pm 0.73)$ respectively.

Ethanolic extract showed potency against all fungal strains except $A$. niger. The highest inhibitory zone was recorded in case of Cryptococcus neoformans $(15.0 \pm 1.0 \mathrm{~mm})$ followed by $C$. albicans $(8.3 \pm 0.81 \mathrm{~mm})$ and $S$. cerevisiae $(7.3 \pm 1.25)$. In case of chloroform leaf extract the antifungal activity was observed against only $A$. niger $(6.16 \pm 1.04 \mathrm{~mm})$. Hexane leaf extract showed inhibitory action against only $C$. albicans $(11.8 \pm 1.70 \mathrm{~mm})$ and $C$. neoformans $(10.86 \pm 1.80 \mathrm{~mm})$. Petroleum ether leaf extract was unable to inhibit the growth of each and every fungal strain (Figure 5). In case of stem, maximum antifungal activity was recorded for chloroform extract against only $C$. neoformans $(9.93 \pm 0.90 \mathrm{~mm})$ followed by ethanol extract against $C$. albicans $(3.2 \pm 0.81)$ and methanolic extract against $A$. niger $(3.1 \pm 0.42)$. 
Table.1 Phytochemical analysis of $V$. negundo leaf and stem extracts

\begin{tabular}{|c|c|c|c|c|c|c|c|c|c|c|c|}
\hline \multirow[t]{2}{*}{ S. No. } & \multirow{2}{*}{$\begin{array}{c}\text { Phytochemical } \\
\text { constituents }\end{array}$} & \multicolumn{2}{|c|}{ MET } & \multicolumn{2}{|c|}{ ETH } & \multicolumn{2}{|c|}{ CHL } & \multicolumn{2}{|c|}{ PE } & \multicolumn{2}{|c|}{ HEX } \\
\hline & & leaf & stem & leaf & Stem & leaf & Stem & leaf & stem & Leaf & Stem \\
\hline 1 & Reducing sugar & - & - & - & - & + & + & - & - & + & + \\
\hline 2 & Phenol & + & - & - & + & - & + & - & + & + & + \\
\hline 3 & Saponin & - & - & + & + & + & - & - & + & - & - \\
\hline 4 & Steroid & - & - & - & + & + & - & - & + & - & - \\
\hline 5 & Coumarin & - & + & - & - & + & + & + & - & + & - \\
\hline
\end{tabular}

Methanol (MET), Ethanol (ET), Chloroform (CHL), Petrolium ether (PE), Hexane (HEX)

Table.2 Antibacterial activity of leaf and stem crude extracts (Disc diffusion method)

\begin{tabular}{|c|c|c|c|c|c|c|c|c|c|c|c|}
\hline \multirow[t]{2}{*}{ S.No } & \multirow[t]{2}{*}{ Microbial strains } & \multicolumn{2}{|c|}{ MET } & \multicolumn{2}{|c|}{ ETH } & \multicolumn{2}{|c|}{ CHL } & \multicolumn{2}{|r|}{ PE } & \multicolumn{2}{|c|}{ HEX } \\
\hline & & Leaf & Stem & Leaf & Stem & Leaf & Stem & Leaf & Stem & Leaf & Stem \\
\hline 1 & S. aureus & $5.63 \pm 077$ & & $7.96 \pm 0.55$ & $8.73 \pm 0.64$ & - & - & - & - & - & - \\
\hline 2 & B. subtilis & $7.33 \pm 0.35$ & - & $7.96 \pm 0.55$ & - & - & - & $13.0 \pm 0.3$ & - & - & - \\
\hline 3 & Pseudomonas & - & - & $5.73 \pm 0.64$ & - & $12.33 \pm 1.5$ & - & $13.0 \pm 0.3$ & $10.33 \pm 0.65$ & $18.53 \pm 1.36$ & - \\
\hline 4 & S. typhi & $2.7 \pm 0.3$ & $8.06 \pm 1.10$ & - & $13.06 \pm 0.90$ & $8.16 \pm 1.2$ & - & $5.56 \pm 1.4$ & - & - & - \\
\hline
\end{tabular}

All values are expressed as Mean \pm Standard deviation of three replicates

Methanol (MET), Ethanol (ETH), Chloroform (CHL), Petroleum ether (PE), Hexane (HEX)

Table.3 Antifungal activity of leaf and stem crude extracts (Disc diffusion method)

\begin{tabular}{|c|c|c|c|c|c|c|c|c|c|c|c|}
\hline \multirow{2}{*}{ S.No } & \multirow{2}{*}{ Microbial strains } & \multicolumn{2}{|c|}{ MET } & \multicolumn{2}{c|}{ ETH } & \multicolumn{2}{c|}{ CHL } & \multicolumn{2}{c|}{ PE } & \multicolumn{2}{c|}{ HEX } \\
\cline { 3 - 11 } & & Leaf & Stem & Leaf & Stem & Leaf & Stem & Leaf & Stem & Leaf & Stem \\
\hline $\mathbf{1}$ & S. cerevisiae & $6.26 \pm 0.73$ & - & $7.3 \pm 1.25$ & - & - & - & - & - & - & - \\
\hline $\mathbf{2}$ & C. albicans & $8.33 \pm 0.57$ & - & $8.3 \pm 0.81$ & $3.2 \pm 0.81$ & - & - & - & - & $11.8 \pm 1.70$ & - \\
\hline $\mathbf{3}$ & C. neoformans & $14.76 \pm 1.42$ & - & $15 \pm 1.0$ & - & - & $9.93 \pm 0.90$ & - & - & $10.86 \pm 1.80$ & - \\
\hline $\mathbf{4}$ & A.niger & $8.33 \pm 1.33$ & $3.1 \pm 0.42$ & - & - & $6.16 \pm 1.04$ & - & - & - & - & - \\
\hline
\end{tabular}

All values are expressed as Mean \pm Standard deviation of three replicates

Methanol (MET), Ethanol (ETH), Chloroform (CHL), Petroleum ether (PE), Hexane (HEX) 
Fig.1 Plant sample

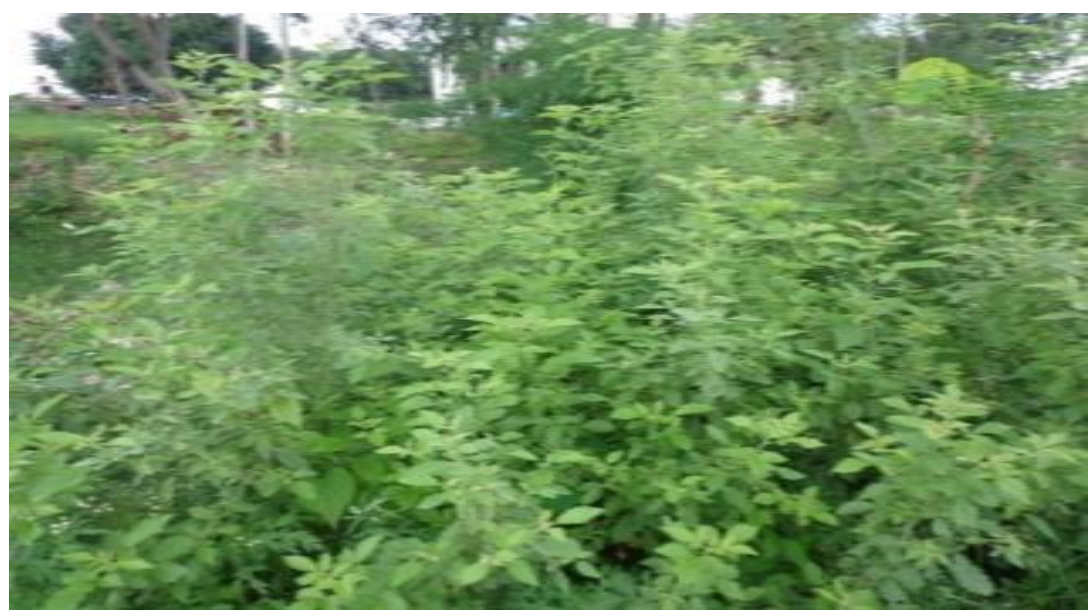

Fig.2 Tests showing presence of: (A)reducing sugar, (B) saponin, (C) phenol, (D) coumarin, (E) steroid

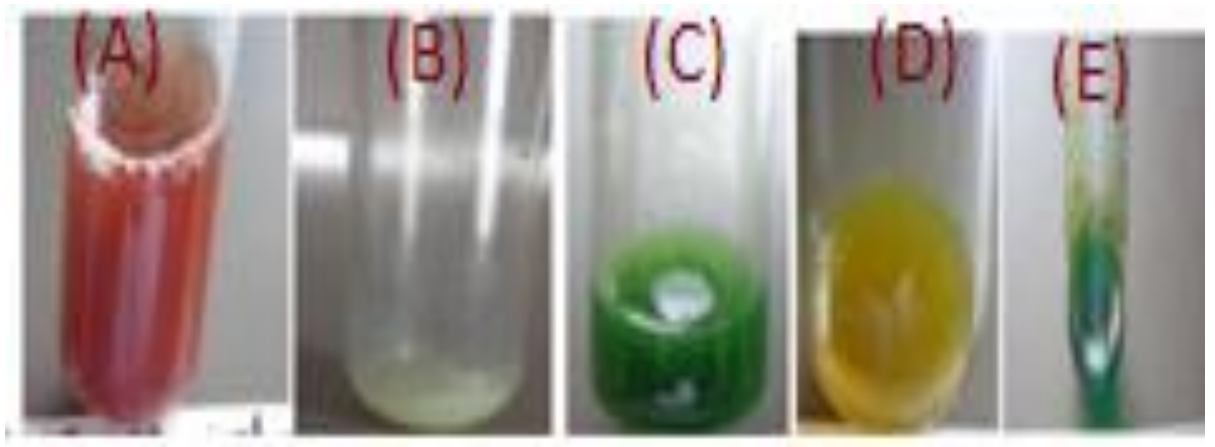

Fig.3 Antibacterial activity of leaf extract

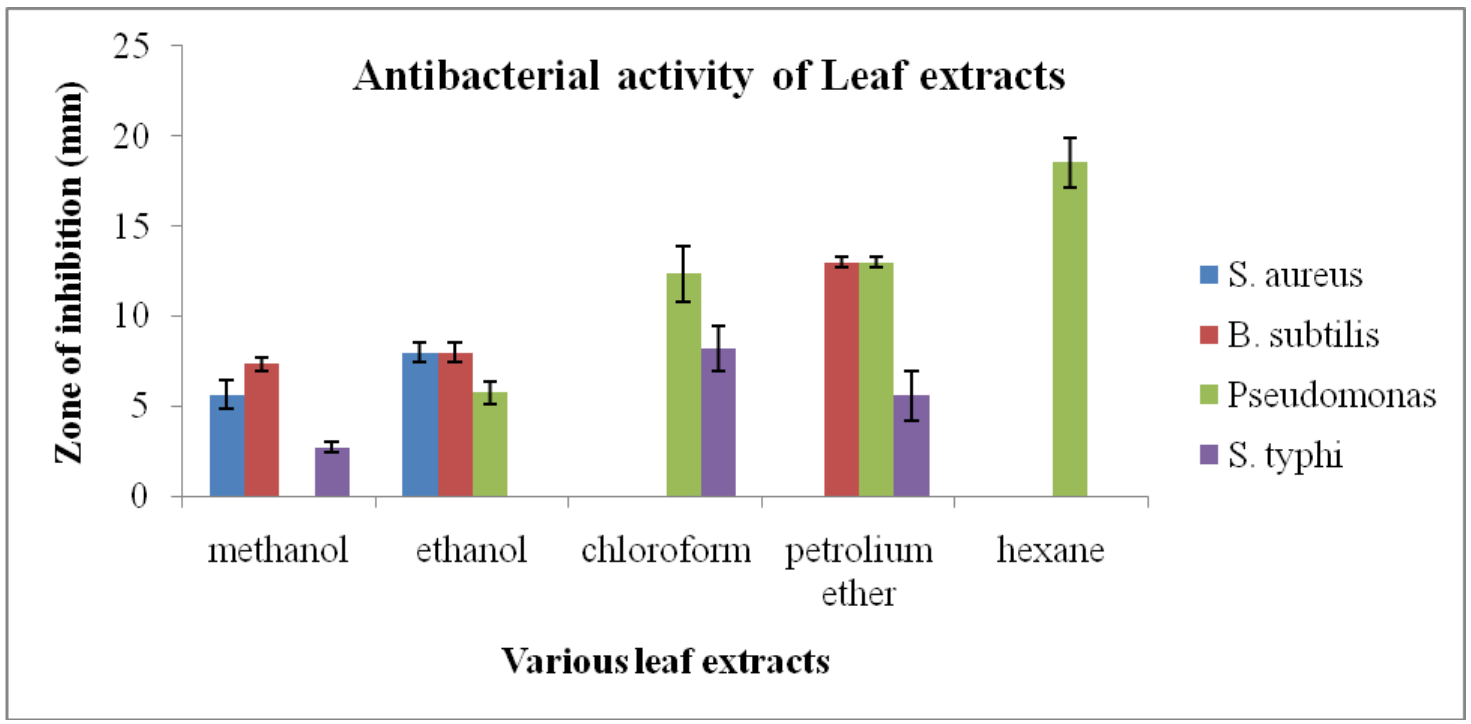


Fig.4 Antibacterial activity of stem extract

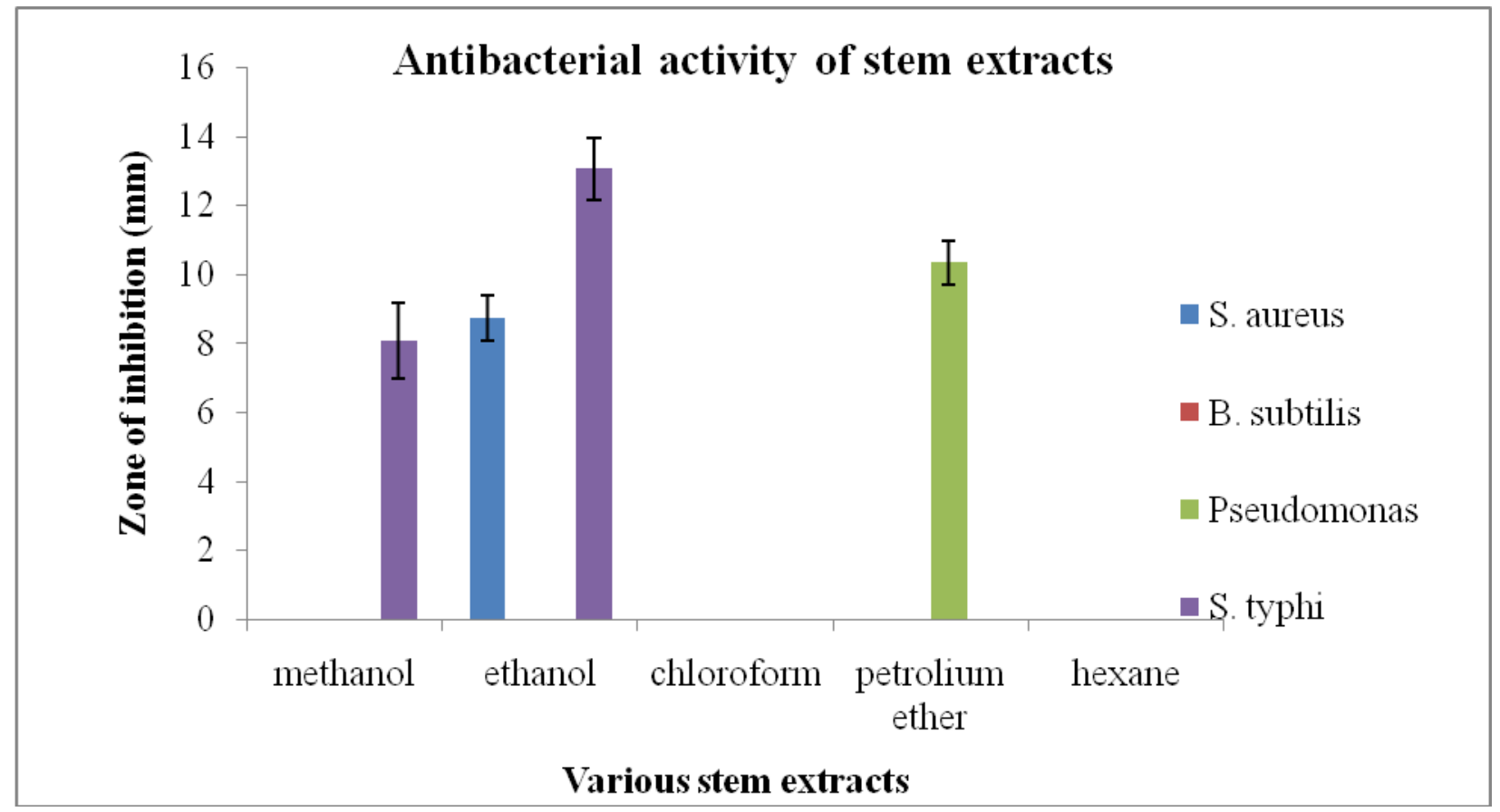

Fig.5 Antifungal activity of leaf extracts

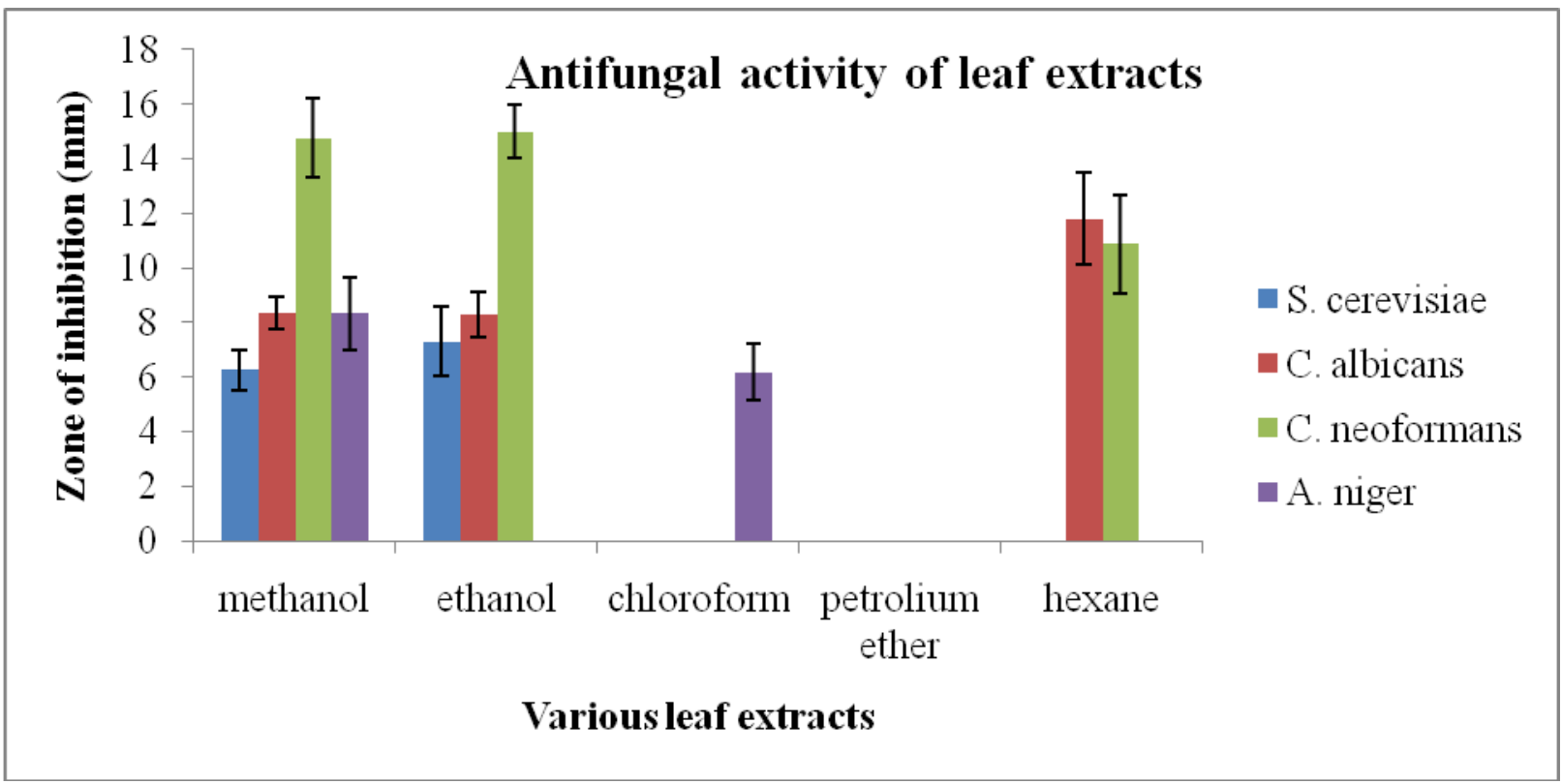


Fig.6 Antifungal activity of stem extracts

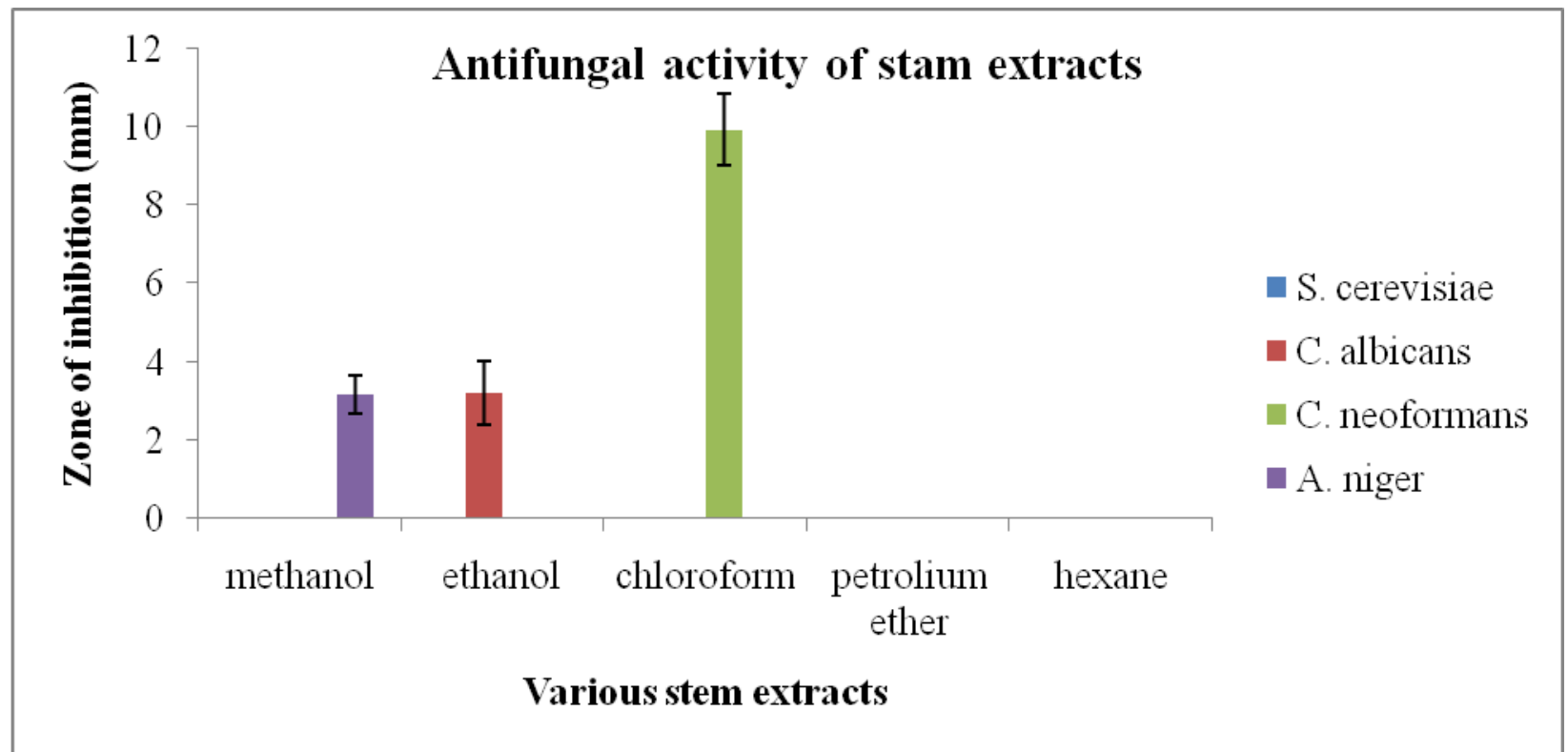

Petroleum ether and hexane extracts showed negative result against all fungal strains (Figure 6). Same study was done by Bameta et al., (2017) in Nerium oleander and found that the methanolic leaf and stem extract were mainly active against fungal cultures. Anbalagan et al., (2017) reported that the ethanol extract of $V$. negundo showed the highest inhibition zone against $C$. albicans and the growth of Penicillium sp. inhibited by methanol extract.

In the present study we conclude that Vitexnegundo leaves and stem have potential to act as a source of useful drugs because of the presence of various phytochemical constituents such as Reducing sugar, phenol, saponins, steroid and coumarin. These constituents seem to have the potential to act as a source of useful drugs and also to improve the health status of consumers as a result of the presence of various compounds that play a vital role for good health.

\section{Acknowledgement}

The Authors wish to express their sincere thanks to Department of Biotechnology \&
Allied Science, M. B. Govt. P. G. College Haldwani Nainital for encouragement and support.

\section{References}

Aboud, A. S. 2015. Antimicrobial activities of aqueous and ethanolic extracts from Nerium oleander used in the treatment of burns infections isolates. J. Pharm. Chem. Biol. Sci., 2(4), 248-258.

Anbalagan S, Sankareswaran M, Moorthy M, Elakkia B and Fahamitha E. (2017) Phytochemical Analysis and Antifungal Activity of Vitex negundo Leaf Extracts Against Clinically Isolated Fungal Pathogens. Indian journal of applied Microbiology 20 (2): 119-125.

Aswar, P.B., Khadabadi, S.S., Kuchekar, B.S., Rajurkar, R.M., Saboo, S.S. and Javarkar, R.D. 2009. In vitro evaluation of anti-bacterial and antifungal activity of Vitexnigundo (Verbenaceae), Ethnobotanical Leaflets. 13, 962-967.

Balick, M.J. and Mendelsohn, R. 1992.Assessing the economic value of 
traditional medicines from tropical rainforests. Conservation Biology 6: $128-129$

Bameta, A., Kumari, A., \&Upadhyaya, A. 2017. Phytochemical analysis and antimicrobial activity of Nerium oleander L. Phytochemical analysis, 2(3).

Banerji, A., Chadha, M.S. and Malshet, V.G. 1969. 'Isolation of 5-hydroxy3,6,7,3,4-pentamethoxyflavone from Vitex negundo'. Phytochemistry. 8, 511-512.

Boisser, M.E.D. 1888. Flora Orientalis. Vol. 4, pp:535. Asher, A. and Co.B.V. Amsterdam

Brindha, P. and Saraswathy, A.1981. Phytochemical comparison of Pentatropis, Oldenlandia and plumeria. In: Proc. Natl. Seminar on Recent Trends in Natural Products Chemistry, held on March 30-31, at Bharathidasan Univ., Tiruchirappalli, India.

Chauhan, NS. 1999. Medicinal \& Aromatic Plants of Himachal Pradesh. New Delhi: Indus Publishing Co.; 1999. p. 436-438.

Chevallier, A. 1996. The Encyclopedia of Medicinal Plants. 1st Ed. (DK Publishing Inc. New York, USA) 55281.

Chitra V., Shrinivas Sharma., and Nandu Kayande. 2009. Evaluation of Anticancer Activity of Vitex negundo in Experimental Animals: An in Vitro and in Vivo Study. Int. J. Pharm. Tech. Res, 1(4): 1485-1489.

Deogade M S, Pandya T, Prasad K S, Kale K, Tankhiwale N 2016) Antimicrobial Activity of Vitex negundo Linn. (Nirgundi) Leaves Extract. J. Res. Tradit. Medicine, 2(4) 99-102.

Dharmasiri M.G., Jayakody J.R.A.C., Galhena G., Liyanage S.S.P. and Ratnasooriyab W.D. 2003.Anti-inflammatory and analgesic activities of mature fresh leaves of Vitex negundo. Journal of Ethnopharmacology. 87, 199-206.

Gautam L.N., Shrestha S.L., Wagle P., and Tamrakar B.M. 2008. Chemical constituents from Vitex negundo of Nepalese origin. Scientific World.6, (6).27-32.

Hussain, A.,Virmani OP., Popli,SP., Mujra, LN., Gupta, MM et al., 1992. Dictionary of Indian medicinal plants, Director, Central Institute of Medicinal and Aromatic plants, Lucknow. 1992, 161-2.

Jadhav A.N. and Bhutani K.K. 2005.Ayurveda and gynecological disorders, Journal of Ethnopharmacology. 97, 151-159.

Jeyachandran R, Baskaran X, Cindrella L (2010) Phytochemical and Antibacterial Potential of Four Indian Medicinal Plants. J Med plants 1(5): 301-306

Kamlesh KB., Vikrantsingh, MG. 2010. Natural products drug discovery research in India: Status and appraisal. Ind J Exp Biol. 2010; 48: 199-207.

Lambert, J., Srivastava, J. and Vietmeyer, N. 1997. Medicinal plants: Rescuing a global heritage, World Bank Publications, 1997.

Mahmud, S., Shareef, H., Farrukh, U., Kamil, A., and Rizwani, G. H. (2009). Antifungal activities of Vitex negundo Linn. Pak. J. Bot, 41(4), 1941-1943.

Maruzella JC, Henry PA. The antimicrobial activity of perfume oils. J. Am. Pharma. Asso. 1958; 28: 471.

Merlin Rose, C., and Cathrine, L. (2011). Preliminary phytochemical screening and antibacterial activity on Vitex negundo. Intern. J. Current Pharm. Res, 3, 99-101.

Panda S.K and Dutta S.K.2009. Antibacterial activity and phytochemical screening of leaf and bark extracts of Vitex negundo L. from similipal biosphere reserve, Orissa. Journal of Medicinal 
Plants Research Vol. 3(4). Pp. 294300(2009).

Raj P.V., Chandrasekhar H.R., Vijayan P., Dhanaraj S.A., Rao C.M., Rao J.V. and Nitesh K. 2008. In vitro and in vivo hepatoprotective effect of Vitex negundo leaves, Pharmacology Online. 3, 281-295.

Rechinger, K.H.1967. (Verbenaceae in patzak, A.; Rechinger, K.H.), Flora Iranica. No: 47.

Samy R.P., Ignacimuthu S. and Sen A. 1998.Screening of 34 Indian medicinal plants for antibacterial properties. Journal of Ethno pharmacology. 62, $173-182$

Sathiamoorthy B., Gupta P., Kumar M., Chaturvedi A.K., Shukla P.K. and
Maurya R. 2007 New antifungal glycoside from Vitex negundo. Bioorganic and Medical Chemistry Letters. 17, 239-242.

Sharma P.V. (2005). CarakaSamhita, Chaukhamba Orientalia.

Tiwari O.P. and Tripathi Y.B. 2007. Antioxidant properties of different fractions of Vitex negundo Linn. Food Chemistry. 100, 1170-1176.

Trease and Evans. 2002. Pharmacognosy; Edited by: Evans WC. W. B Saunders; 2002; 15: p. 481.

Valasraj R, Pushpangadan P, Smith UW, Adersen A, Nyman U. 1997. Antimicrobial screening of selected medicinal plants from India. J. Ethnopharmacol. 58: 75 - 83, (1997).

\section{How to cite this article:}

Alka Bameta, Shruti Sanwal and Sonu Ambwani. 2019. Phytochemical Screening and Antimicrobial Activity of Vitex negundo Leaf and Stem Extracts against Bacterial and Fungal Pathogens. Int.J.Curr.Microbiol.App.Sci. 8(12): 1071-1081. doi: https://doi.org/10.20546/ijcmas.2019.812.136 